Volume 46 Number 4 September 2017

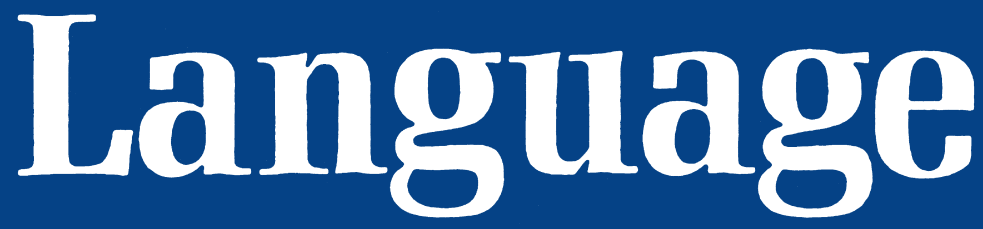

in Society 


\title{
LANGUAGE IN SOCIETY
}

FOUNDING EDITOR: Dell Hymes

\author{
EDITOR \\ JENNY CHESHIRE \\ Queen Mary University of London, UK
}

\author{
ASSOCIATE EDITORS \\ Judith T. Irvine \\ University of Michigan, USA
}

Jan Blommaert

Tilburg University, The Netherlands

Jack Sidnell

University of Toronto, Canada

Deborah Tannen

Georgetown University, USA

\author{
REVIEWS EDITOR \\ Brian W. King \\ City University of Hong Kong, \\ Hong Kong
}

\section{EDITORIAL BOARD}

Samy Alim, Stanford Graduate School of Education, USA Elaine Chun, University of South Carolina, USA

Paul Drew, Loughborough University, UK

Susan Gal, University of Chicago, USA

Penelope Gardner-Chloros, Birkbeck, University of London, UK

Cynthia Gordon, Georgetown University, USA

Frans Gregersen, University of Copenhagen, Denmark

Lenore Grenoble, University of Chicago, USA

Monica Heller, University of Toronto, Canada

Janet Holmes, Victoria University of Wellington, New Zealand

Adam Jaworski, University of Hong Kong, Hong Kong

Elizabeth Keating, University of Texas, Austin, USA

Scott F. Keating, University of Pittsburgh, USA

Paul Kerswill, University of York, UK

Erez Levon, Queen Mary, University of London, UK

Yael Maschler, University of Haifa, Israel
Tommaso M. Milani, University of the Witwatersrand, South Africa

Miriam Meyerhoff, Victoria University of Wellington, New Zealand

Lorenza Mondada, University of Basel, Switzerland

Emma Moore, University of Sheffield, UK

Greg Myers, University of Lancaster, UK

Ingrid Piller, Macquarie University, Australia

Anne Pomerantz, Graduate School of Education,

University of Pennsylvania, USA

Ben Rampton, King's College London, UK

Otto Santa Ana, University of California, Los Angeles, USA

Adam Schembri, University of Birmingham, UK

Jeff Siegel, University of New England, Australia

Jane Stuart-Smith, University of Glasgow, UK

Tanya Stivers, University of California, Los Angeles, USA

Crispin Thurlow, University of Bern, Switzerland

Editorial Assistant: Scott Lewis, Queen Mary University of London, UK

Editorial Policy: Language in Society is an international journal of sociolinguistics concerned with all branches of speech and language as aspects of social life. The journal includes empirical articles of general theoretical, comparative or methodological interest. Content varies from predominantly linguistic to predominantly social. Language in Society aims to strengthen international scholarship and cooperation in this field. In addition to original articles, the journal publishes reviews of current books in the field.

Subscriptions: Language in Society (ISSN 0047-4045) is published five times annually in February, April, June, September, and November by Cambridge University Press: One Liberty Plaza, New York, NY 10006, U.S.A.; and University Printing House, Shaftesbury Road, Cambridge CB2 8BS, England. Annual subscription rates for Volume 46, 2017: Institutional print and electronic rates, US \$609.00 in the U.S.A., Canada, and Mexico, UK $£ 379.00+$ VAT elsewhere. Institutional electronic rates only, US $\$ 486.00$ in the U.S.A., Canada, and Mexico, UK $£ 303.00+$ VAT elsewhere. Institutions print rates only, US \$585.00 in the U.S.A., Canada, and Mexico, UK $£ 356.00+$ VAT elsewhere. Individuals print only, US $\$ 140.00$ in the U.S.A., Canada, and Mexico, UK $£ 85.00+$ VAT elsewhere. Prices include postage and insurance.

Institutional subscribers: Access to full-text articles online is currently included with the cost of print and electronic subscriptions. Subscription must be activated; see cambridge.org/core for details. Information on Language in Society and all other Cambridge journals is available via cambridge.org/core. Full text for this journal can be found at cambridge.org/lsy.

Periodicals postage paid at New York, NY, and additional mailing offices. Postmaster: Send address changes in the U.S.A., Canada, and Mexico to: Language in Society, Journals Department, Cambridge University Press, One Liberty Plaza, New York, NY 10006.

Claims for missing issues should be made immediately after receipt of the next issue.

Copyright (C) 2017 Cambridge University Press: All rights reserved. No part of this publication may be reproduced, in any form or by any means-electronic, photocopying, or otherwise-without permission in writing from Cambridge University Press. For further information please visit http://us.cambridge.org/information/ rights/.

Photocopying information for users in the U.S.A. The Item-Fee Code for this publication $(0047-4045 / 15 \$ 15.00)$ indicates that copying for internal or personal use beyond that permitted by Sec. 107 or 108 of the U.S. Copyright Law is authorized for users duly registered with the Copyright Clearance Center (CCC) Transaction Reporting Service, provided that the appropriate remittance per article is paid directly to: CCC, 222 Rosewood Drive, Danvers, MA 01923.

Specific written permission must be obtained from Cambridge University Press for all other copying.

Advertising: about advertising should be sent to the Journals Promotion Department of the New York Cambridge University Press office (journals_advertising@cambridge.org). 